\title{
Distribution of Phytoplasmas in Infected Plants as Revealed by Real-Time PCR and Bioimaging
}

\author{
Nynne Meyn Christensen, ${ }^{1}$ Mogens Nicolaisen, ${ }^{2}$ Michael Hansen, ${ }^{1}$ and Alexander Schulz ${ }^{1}$ \\ ${ }^{1}$ Department of Plant Biology, The Royal Veterinary and Agricultural University, Thorvaldsensvej 40, DK-1871 Frederiksberg \\ C, Copenhagen, Denmark; ${ }^{2}$ Danish Institute of Agricultural Sciences, Department of Crop Protection, Research Centre \\ Flakkebjerg, DK-4200 Slagelse, Denmark
}

Submitted 5 February 2004. Accepted 12 July 2004.

\begin{abstract}
Phytoplasmas are cell wall-less bacteria inhabiting the phloem and utilizing it for their spread. Infected plants often show changes in growth pattern and a reduced crop yield. A quantitative real-time polymerase chain reaction (Q-PCR) assay and a bioimaging method were developed to quantify and localize phytoplasmas in situ. According to the Q-PCR assay, phytoplasmas accumulated disproportionately in source leaves of Euphorbia pulcherrima and, to a lesser extent, in petioles of source leaves and in stems. However, phytoplasma accumulation was small or nondetectable in sink organs (roots and sink leaves). For bioimaging, infected plant tissue was stained with vital fluorescence dyes and examined using confocal laser scanning microscopy. With a DNA-sensitive dye, the pathogens were detected exclusively in the phloem, where they formed dense masses in sieve tubes of Catharanthus roseus. Sieve tubes were identified by counterstaining with aniline blue for callose and multiphoton excitation. With a potentiometric dye, not all DNA-positive material was stained, suggesting that the dye stained metabolically active phytoplasmas only. Some highly infected sieve tubes contained phytoplasmas that were either inactive or dead upon staining.
\end{abstract}

Phytoplasmas are cell wall-less bacteria inhabiting the phloem sieve elements in infected plants. They have been associated with diseases in several hundred plant species, including many important crops (Lee et al. 2000; McCoy et al. 1989). While crop failure caused by these pathogens is a severe economic problem, infection produces a desired, bushy growth form in the case of Euphorbia pulcherrima (poinsettia) (Lee et al. 1997a). The mechanism of plant-phytoplasma interaction is not yet resolved. Several studies indicate that phytoplasmas alter endogenous phytohormone levels in host plants, thus causing symptoms such as proliferation of axillary shoots, virescence, or phyllody. More recent studies do not support a direct effect on phytohormones (Lee et al. 2000). Phytoplasma infection severely impairs assimilate translocation in host plants and might be responsible for subtle changes in the bioenergetics of the phloem (Lepka et al. 1999). The mechanism behind the movement of phytoplasmas observed in different infected plant species is not known (Garcia-Chapa et al. 2003; Seemüller et al. 1984; Siddique et al. 1998). Movement occurs in the direction of the phloem stream from source

Corresponding author: A. Schulz; E-mail: als@kvl.dk to sink. However, other factors for movement are implicated, because phytoplasmas spread more slowly than solutes and sometimes are not detectable in sink tissue (Constable et al. 2003; Schaper and Seemüller 1984).

Phytoplasmas have resisted all attempts to be cultivated in vitro in cell-free media. Development of molecular-based tools, in particular polymerase chain reaction (PCR) using either phytoplasma-specific primers or phytoplasma groupspecific primers, has not only greatly increased the sensitivity of detection in the host tissue but also allowed for the identification and classification of phytoplasmas (Ahrens and Seemüller 1992; Laimer da Câmara Machado et al. 2001; Lee et al. 1997b, 1998a, 2000; Lim and Sears 1989; Seemüller et al. 1998). Phytoplasmas rarely have been subjected to quantification. The methods used include competitive PCR, nested competitive PCR, and quantitative DNA hybridization (Berges et al. 2000; Blomquist and Kirkpatrick 2002; Jarausch et al. 1998). Compared with competitive PCR, quantitative real-time PCR (Q-PCR) methods do not rely on equal amplification of an internal standard (Giulietti et al. 2001). Recently, Wei and associates (2004) reported a Q-PCR method capable of detection of a specific phytoplasma (OY strain).

Microscopic methods for detection in the plant require tissue fixation. Transmission electron microscopy (TEM) revealed the presence of phytoplasmas in sieve tubes and neighboring cells in heavily infected host plants (RudzinskaLangwald and Kaminska 1999; Siddique et al. 1998; Siller et al. 1987). Fluorescence microscopy with the DNA-specific 6diamidino-2-phenylindole (DAPI) is more sensitive than either TEM or light microscopy (Deeley et al. 1979; Lederer and Seemüller 1992), but is not phytoplasma specific (Jarausch et al. 1998; Sinclair et al. 2000). Live observation of phytoplasmas is not possible with any of the previous methods. Bioimaging methods, where neither the target tissue nor the physiology of phytoplasmas are disturbed, require highly sensitive, specific, and nontoxic fluorescent dyes, the use of confocal or multiphoton microscopy, and a clear identification of the phloem tissue.

Recently, the complete sequence of the genome of the phytoplasma OY strain (Candidatus Phytoplasma asteris) was published (Oshima et al. 2004). For the optimal utilization of the sequence, enhanced tools for monitoring phytoplasmas in their interaction with the host are required. Phytoplasma gene expression studies will, for example, require the accurate estimation of phytoplasma content in different plant tissues. In this study, a Q-PCR assay and a bioimaging method were developed to quantify and localize a wide range of phy- 
toplasma strains. The techniques were used to examine phytoplasmas in Catharanthus roseus and E. pulcherima.

\section{RESULTS}

Specificity and sensitivity of the Q-PCR assay.

A Q-PCR assay using the $16 \mathrm{~S}$ ribosomal gene was developed for detection and quantification of phytoplasma strains. A broad range of phytoplasma strains belonging to different subgroups of the phytoplasma 16S rDNA gene were detected using the assay (Table 1). Cross reactivity of the primers and probe with DNA from bacteria unrelated to phytoplasma was checked. When undiluted DNA was used, very low signals or no signals were observed (Table 1).

To test the sensitivity of the Q-PCR assay, the threshold number of PCR cycles $\left(\mathrm{C}_{\mathrm{T}}\right)$ for dilution series of infected $C$. roseus tissue and infected $E$. pulcherrima tissues was plotted against the relative concentration on a semi-logarithmic scale, resulting in regression lines from $C$. roseus (Fig. 1A) and $E$. pulcherrima (Fig. 1B) with regression coefficients of 0.9918 and 0.9992 , respectively. The detection limit of the assay was assessed using the same dilution series and compared with nested PCR as an established method. Nested PCR detected phytoplasmas in infected $C$. roseus down to a dilution limit of $10^{-5}$ (Fig. 1C), whereas the Q-PCR assay was able to detect down to at least $10^{-6}$ (Fig. 1A). For E. pulcherrima, the detection limit of both nested and real-time PCR was $10^{-5}$ (compare Fig. 1B and C). Furthermore, DNA from infected and uninfected $C$. roseus shoot tissue was mixed in known ratios rang- ing from 100 to $1 \%$ and resulted in a dilution of phytoplasmal DNA relative to plant DNA. Plotted against the found normalized mean quantity, data fell on a straight line with a regression coefficient of 0.9881 (Fig. 2). The linearity over a range of concentrations and sensitivity greater or equal to nested PCR indicates that this assay offers an accurate method for quantification of phytoplasmas and has a detection limit that is comparable with nested PCR.

\section{Distribution of phytoplasmas in infected plants.}

Q-PCR assays of phytoplasma 16S DNA were used to determine the distribution of phytoplasmas within infected $E$. pulcherrima plants and to compare with infected $C$. roseus plants (Table 2). For the quantification of phytoplasmas, a dilution of a PCR product produced from phytoplasma 16S rDNA was used as template in a standard curve for phytoplasma DNA. The sample data were normalized for input amount of DNA using a QPCR assay for plant 18S rDNA. For this assay, a dilution of DNA from healthy E. pulcherrima was used as template in a standard curve for plant DNA. Having the two standard curves with known input amount of DNA and assuming equal PCR efficiency for templates used for standard curves and samples, the number of phytoplasma cells per microgram of plant DNA was calculated. According to this calculation, the infection level varied from $5.3 \times 10^{2}$ cells $/ \mu$ g of plant DNA (roots) to $3.7 \times 10^{5}$ cells $/ \mu \mathrm{g}$ of plant DNA (source petiole) in E. pulcherrima, and up to $4.8 \times 10^{6} \mathrm{cell} / \mathrm{s} / \mathrm{g}$ of plant DNA in $C$. roseus.

Accumulation of phytoplasmal DNA followed the same pattern in all infected E. pulcherrima plants studied (four individ-

Table 1. Strains of phytoplasmas and other bacteria tested with TaqMan assay ${ }^{\mathrm{a}}$

\begin{tabular}{|c|c|c|c|}
\hline Bacteria, isolate & Description & Ribosomal subgroup & $\mathbf{C}_{\mathbf{T}}$ \\
\hline \multicolumn{4}{|l|}{ Phytoplasma } \\
\hline AAY & American aster yellows & 16SrI-B & 17.93 \\
\hline ALY & Alder Yellows & $16 \mathrm{SrV}-\mathrm{C}$ & 19.64 \\
\hline AP15 & Apple proliferation & $16 \mathrm{SrX}-\mathrm{A}$ & 20.85 \\
\hline ASHY & Ash yellows & 16SrVII & 19.21 \\
\hline $\mathrm{AT} 4^{\mathrm{b}}$ & Grapevine yellows, Asti & $16 \mathrm{SrV}-\mathrm{C}$ & 28.02 \\
\hline $\mathrm{BN}^{\mathrm{b}}$ & Bois noir & 16SrXII-A & 28.53 \\
\hline BVK & Flower stunting & 16SrXI & 22.71 \\
\hline $\mathrm{CR}$ & Crepis biennis yellows & 16SrIII-B & 23.81 \\
\hline GSFY-1 & German stone fruit yellows & 16SrX-B & 21.02 \\
\hline GVX & Green valley X & 16SrIII-A & 18.91 \\
\hline JWB & Jujube witches' broom & $16 \mathrm{SrV}-\mathrm{B}$ & 24.28 \\
\hline KVF & Clover phyllody & 16SrI-C & 19.63 \\
\hline $\mathrm{LI}^{\mathrm{b}}$ & Grapevine yellows, Liguria & $16 \mathrm{SrV}-\mathrm{C}$ & 23.44 \\
\hline LUM & Lucerne virescence & 16SrVI & 17.32 \\
\hline MI $259^{\mathrm{b}}$ & Grapevine yellows, Milan & $16 \mathrm{SrV}-\mathrm{C}$ & 27.76 \\
\hline MOL & Sour cherry & 16SrXII-A & 16.24 \\
\hline $\mathrm{PC} 3^{\mathrm{b}}$ & Grapevine yellows, Piacenza & $16 \mathrm{SrV}-\mathrm{C}$ & 29.53 \\
\hline PEY & Pichris echioides yellows & 16SrIX & 22.34 \\
\hline PoiBI & Poinsettia branch-inducing & 16 SrIII-H & 22.02 \\
\hline $\mathrm{PR}^{\mathrm{b}}$ & Grapevine yellows, Parma & 16SrV-D & 25.95 \\
\hline RuS & Rubus stunt & 16SrV-E & 21.28 \\
\hline SEPN & Sesame phyllody & 16SrII-A & 18.91 \\
\hline ULW & Elm yellows & $16 \mathrm{SrV}-\mathrm{A}$ & 19.61 \\
\hline Control & Healthy Euphorbia pulcherrima & $\ldots$ & - \\
\hline \multicolumn{4}{|l|}{ Other bacteria } \\
\hline Agrobacterium radiobacter & $\ldots$ & $\ldots$ & - \\
\hline Arthrobacter globiformis & $\ldots$ & $\ldots$ & 35.54 \\
\hline A. oxydans & $\ldots$ & $\ldots$ & 37.37 \\
\hline Bacillus gibsonii & $\ldots$ & $\ldots$ & - \\
\hline B. megaterium & $\ldots$ & $\ldots$ & - \\
\hline Clavibacter michiganense & $\ldots$ & $\ldots$ & 37.40 \\
\hline Paenibacillus macerans & $\ldots$ & $\ldots$ & 36.99 \\
\hline Pseudomonas putida & $\ldots$ & $\ldots$ & 37.52 \\
\hline Ralstonia pickettii & $\ldots$ & $\ldots$ & - \\
\hline Rhodococcus equi & $\ldots$ & $\ldots$ & 35.43 \\
\hline
\end{tabular}

${ }^{a}$ Threshold number of polymerase chain reaction cycles $\left(\mathrm{C}_{\mathrm{T}}\right)$ is indicated. Data represent two TaqMan assays, the first including the phytoplasma strains and the second the other bacteria.

${ }^{\mathrm{b}}$ Vitis vinifera (grapevine) was host instead of Catharanthus roseus, in which the rest of the phytoplasma strains were cultivated. 
ual plants). No phytoplasmas were detected in sink tissues. Levels were low in roots and moderate in stems (five to eight times higher titer than in roots). The highest titer was found in source petioles (10 to 15 times higher titer than in roots) and source leaves $(\approx 40$ times higher titer than in roots) (Table 2 , plant E). Sink leaves were analyzed in a total of four additional Q-PCR assays and phytoplasmal DNA was below detection (data not shown).

Variation in the amount of phytoplasma DNA between individual E. pulcherrima plants was relatively large (Table 2). Plant B had the highest titer of phytoplasma, despite the fact that all test plants were propagated from one infected parent plant. Accumulation within the same tissue at different time points (within a few weeks) varied with a factor of 2 to 4 in relative amounts but, again, the tissue of plant $B$ had a much higher titer of phytoplasma than the other plants (data not shown). Plant B also showed stronger symptoms than plant A, $\mathrm{C}$, and $\mathrm{E}$, being more branched than these. Large differences in the infection level between $E$. pulcherrima and $C$. roseus with a factor of $10^{2}$ to $10^{4}$ (depending on the tissue compared) were detected (Table 2). Control plants did not show any evidence of phytoplasmal DNA.

\section{Bioimaging.}

Allium cepa bulb scale epidermis was used to screen for vital dyes that are sufficiently sensitive to detect mitochondria, which have similar properties as phytoplasmas. Among the tested dyes, two were found suitable. The DNA-specific SYTO 13 stained the DNA of the nucleus in a fresh A. cepa peel (Fig. $3 \mathrm{~A})$ and the mitochondria in the peripheral cytoplasm of the epidermis cells (Fig. 3B and C). SYTO 13 did not stop streaming in the epidermis cells and allowed detection of mitochondrial DNA $3 \mathrm{~h}$ after application. Photobleaching (loss of fluorescence) was minimal during scanning, making SYTO 13 suitable for prolonged recordings or high-magnification imaging of an area. $\mathrm{DiOC}_{7}(3)$ stained mitochondria but not the nuclei of $A$. cepa epidermis cells (Fig. 3D). Continuation of cytoplasmic streaming confirmed $\mathrm{DiOC}_{7}(3)$ as a vital stain. However, this dye caused more photobleaching than SYTO 13, limiting the number of recordings from one region of exposure.

Aniline blue was used as a specific dye for callose in order to identify sieve tubes. Aniline blue was first tested for toxicity in A. cepa. With the chosen concentration, cytoplasmic streaming did not stop during image recording. Aniline blue normally is excited with UV light. The use of a UV-laser turned out to be unsuitable because of strong bleaching effects and damage to cells. Instead, multiphoton excitation was used.

Longitudinal stem sections from infected $C$. roseus and $E$. pulcherrima are shown in Figure $3 \mathrm{E}$ and $\mathrm{F}$, respectively, stained with SYTO 13 and counterstained with aniline blue. SYTO 13 fluorescence is depicted in red while aniline-blue callose fluorescence is in green. In $C$. roseus, SYTO 13 fluorescence almost completely filled the cell lumen of most sieve tubes, indicating a dense mass of phytoplasmas (also evident in Fig.
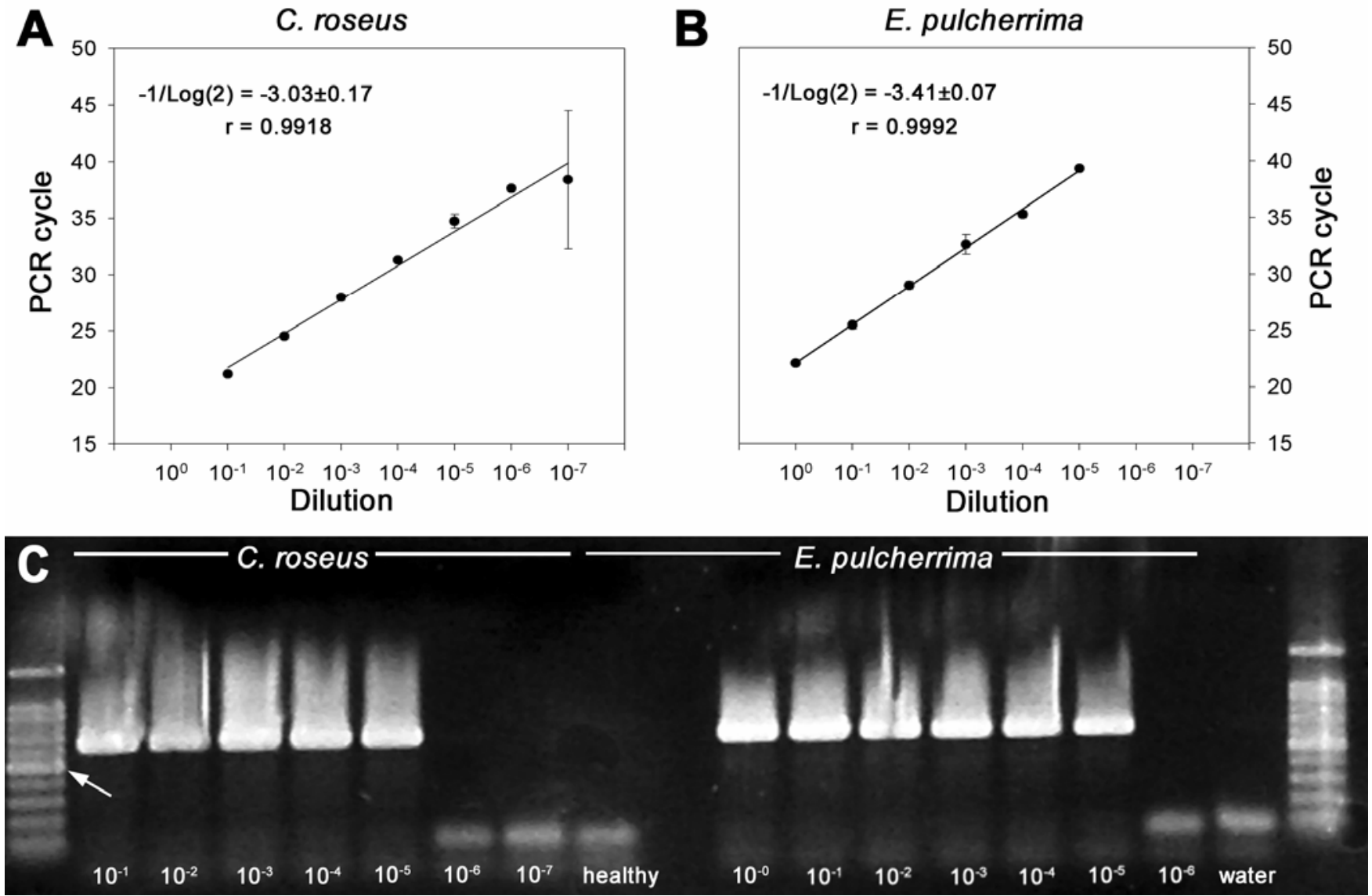

Fig. 1. Sensitivity of nested polymerase chain reaction (PCR) and quantitative real-time (Q)-PCR. A, Q-PCR of a dilution series $\left(10^{-1}\right.$ to $\left.10^{-7}\right)$ of an infected Catharanthus roseus shoot. The threshold numbers of PCR cycles $\left(\mathrm{C}_{\mathrm{T}}\right.$ value; means of triplicates) are plotted against the dilution (log scale). Linear regression coefficient $(r)$ is given with the equation in the graph. Large error bars occur in dilution $10^{-7}$ only, reflecting a larger variability in $\mathrm{C}_{\mathrm{T}}$. Accordingly, the dilution of $10^{-7}$ is on the detection limit. B, Q-PCR of an Euphorbia pulcherrima dilution series $\left(10^{0}\right.$ to $\left.10^{-6}\right)$ of an infected E. pulcherrima petiole. The $\mathrm{C}_{\mathrm{T}}$ values (means of triplicates) are plotted against the dilution (log scale). Linear regression coefficient $(r)$ is given with the equation in the graph. Dilution $\left(10^{-6}\right)$ has not been considered since only one of the triplicates came above the baseline. C, Agarose gel of nested PCR showing a dilution series from C. roseus (same as in A), a negative control of healthy E. pulcherrima, a dilution series from E. pulcherrima (same as in B), and a water control. On each side a marker (100 bp) has been loaded, arrow marking $500 \mathrm{bp}$. A signal is detected in the wells down to $10^{-5}$ in both C. roseus and E. pulcherrima. 
3J). In other sieve tubes, individual phytoplasmas could be discriminated (Fig. 3E, arrows). The overall fluorescence in the phloem reflects a heavy infection in $C$. roseus samples. An area of the sieve tube fluorescence in Figure $3 \mathrm{E}$ was used for a lambda scan confirming the emission curve to correspond to the DNA-specific fluorescence found in A. cepa peels (data not shown). In E. pulcherrima, only a few sieve tubes in a longitudinal section showed SYTO 13 fluorescence (Fig. 3F, arrows), and sections could be found where no SYTO 13 fluorescence was seen (Fig. 3G), indicating a lower degree of phytoplasma infection in E. pulcherrima than in C. roseus.

Control sections of uninfected $C$. roseus showed only sieveplate callose and nuclei in phloem parenchyma and companion cells, but no SYTO 13-specific fluorescence in sieve tubes (Fig. $3 \mathrm{H}$ ). Infected $C$. roseus sieve tubes did not show any autofluorescence in the SYTO 13 channel as seen when stained with aniline blue alone (Fig. 3I), whereas the infection clearly became visible when adding SYTO 13 (Fig. 3I and J).

No autofluorescence was observed when staining with $\mathrm{DiOC}_{7}(3)$. Healthy $C$. roseus showed fluorescence from chloroplasts and mitochondria, but not in the sieve tubes (Fig. 4A). When infected $C$. roseus was stained with this dye, fluorescence in sieve tubes and from organelles in parenchyma cells was evident (Fig. 4E). The fluorescence found in the sieve tubes was analyzed with a lambda scan, confirming the emission curve to be similar to that found for $\mathrm{DiOC}_{7}(3)$ in stained A. cepa peels (data not shown). It was possible to use the two phytoplasma stains $\operatorname{DiOC}_{7}(3)$ and SYTO 13 in sequence with a device allowing the mounting fluid to be changed while the specimen remained on the microscope stage. The healthy control showed $\mathrm{DiOC}_{7}(3)$-positive organelles across the entire sec- tion, but no fluorescence in the sieve tubes. The same sieve tubes were negative after a subsequent SYTO 13 staining (Fig. 4A and B). This enabled comparison of the staining patterns in infected specimens. SYTO 13 stained more sieve tubes more intensely than $\mathrm{DiOC}_{7}(3)$ (compare Fig. 4C-D and 4E-F, respectively). The different staining patterns do not reflect differences in the infection level, because the same sieve tubes were studied. The difference in staining intensity may be due to nonviable phytoplasmas stained with SYTO 13 but not with $\mathrm{DiOC}_{7}(3)$.

\section{DISCUSSION}

Two novel methods to study the presence, distribution, and physiology of phytoplasmas in plants were designed. The QPCR method provided sensitive and quantifiable data for phytoplasma cells. Infected plants contained the highest concentration of phytoplasmas in source regions, indicating that phytoplasmas multiply fastest here. The bioimaging method detected phytoplasmas in sieve tubes using vital dyes specific for DNA and membrane potential, respectively. Used consecutively, the dyes allowed physiologically active phytoplasma cells to be discriminated from the total population in a given phloem region.

In addition to Q-PCR, this study incorporated primers and probes that were designed to detect a broad range of phytoplasma strains belonging to several $16 \mathrm{~S}$ rDNA subgroups of phytoplasma, but excluding the detection of other DNA. A selection of gram-positive and -negative bacteria showed little or no positive reaction when undiluted DNA was used as template. Using undiluted DNA, a certain amount of mispriming

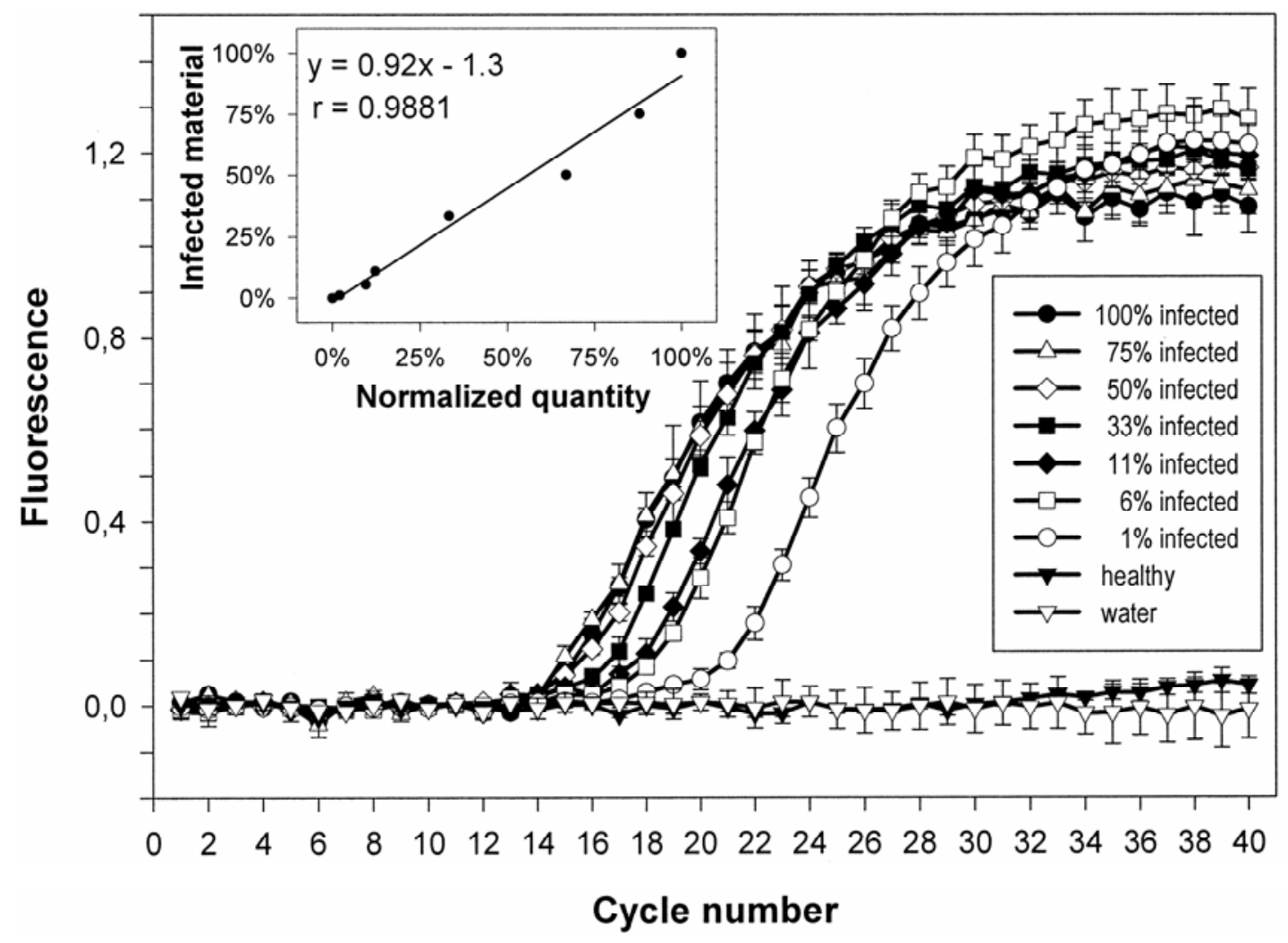

Fig. 2. Quantification of phytoplasmas in plant tissue. Raw data from a quantitative real-time polymerase chain reaction assay of DNA extracted from mixed homogenates of infected and healthy shoot tissue from Catharanthus roseus. Curves are means of triplicates and correspond to the percentage of infected material $(100,75,50,33,11,6$, and $1 \%)$ and, as controls, healthy shoot tissue and water. The three samples with most infected tissue (100, 75, and 50\%) came up close together. The inset shows the effect of using plant DNA as internal standard, because the three most infected samples are separated after normalization. The normalized quantity values from the assay are plotted against the percentage infected material. The linear regression coefficient $(r)$ is given with the equation in the graph. 
can be expected. Predicted on sequence alignments, the assay also might detect the closely related Acholeplasma sp. which has been observed on the surface of some plants (Tully et al. 1994). However, positive results never were observed when analyzing phytoplasma-free material.

This Q-PCR assay was comparable in sensitivity to nested (nonquantitative) PCR in a direct comparison which is in agreement with reports on other organisms and viruses (Bates et al. 2001; Hristova et al. 2001; Shi et al. 1999, Weller et al. 2000). The sensitivity is comparable with the competitive nested PCR assay developed for phytoplasmas by Berges and associates (2000). High sensitivity and easy handling, together with a potential for high throughput, makes Q-PCR the method of choice for studying the specific interaction between phytoplasmas and host plants. This requires measurements of many small biomass samples in different plant organs over time.

For quantification of the infection level, it is necessary to normalize Q-PCR data (Giulietti et al. 2001; Roberts et al. 2000). In the present article, plant $18 \mathrm{~S}$ rDNA served to normalize data. The linear relationship achieved in experiments with known amounts of infected plant tissue indicates that $18 \mathrm{~S}$ rDNA is well suited for normalization in Q-PCR assays. Infection level in the infected plants was in the range of $5.3 \times 10^{2}$ to $3.7 \times 10^{5}$ cells $/ \mu \mathrm{g}$ of plant DNA in E. pulcherrima and $4.8 \times$ $10^{6}$ cells $/ \mu \mathrm{g}$ of plant DNA in $C$. roseus, assuming that two sets of ribosomal genes exist in phytoplasmas (Oshima et al. 2004, Schneider and Seemüller 1994). However, quantification of uncultivated microorganisms is subject to methodological limitations. For example, DNA extraction efficiency and number of genome copies per bacterium cell are not known (Suzuki et al. 2000). Bacteria in the logarithmic growth phase can have multiple copies of their genomes in one cell; however, the growth phase of phytoplasmas cannot be determined in planta.

Based on DNA measurements, large differences in the phytoplasma titer were found within and between individual plants, as well as between the two plant species investigated. Source leaves in E. pulcherrima have a much higher level of infection than sink leaves or roots. The translocation of phytoplasma in the plant is not well understood. Due to their plasticity and size, phytoplasmas can pass sieve plate pores
(Rudzinska-Langwald and Kaminska 1999; Siller et al. 1987) and, therefore, translocation with the assimilate flow is possible. However, a passive translocation with assimilates is supported by neither the present study nor results obtained for the recolonization or distribution of phytoplasma in other plants (Constable et al. 2003; Kuske and Kirkpatrick 1992; Schaper and Seemüller 1984). Possible explanations for the accumulation in source leaves are that phytoplasmas are attached to the sieve-element plasma membrane, retained in the sieve pores, or are self-mobile. In addition, multiplication may be higher in source leaf phloem due to more favorable conditions for growth. However, the latter possibility cannot alone account for the small amount of phytoplasmas in sink tissues such as the root system. The relatively long infection time (more than 3 months) should allow for a continuous accumulation of phytoplasmas in roots. A high number of phytoplasmas in the phloem of source leaves will have consequences for assimilate transport. One possible consequence is the large increase in soluble carbohydrates and starch in source leaves of $C$. roseus infected with phytoplasmas, while soluble carbohydrates were almost unaltered in sink leaves and roots and starch levels in the root were reduced (Lepka et al. 1999). These physiological symptoms are similar to an inhibition of phloem loading by antisensing a sucrose membrane transporter, or to cold-girdling the transport pathway (Schulz et al. 1998), and indicate that phloem loading or assimilate export from source leaves are inhibited by phytoplasma colonization.

The preliminary results of the present study suggest that the degree of infection is correlated with the level of visual symptoms in E. pulcherrima. Previous reports on phytoplasma infection of E. pulcherrima and C. roseus are in agreement with the observation of a low phytoplasma titer in E. pulcherrima compared with $C$. roseus. $C$. roseus often has a much higher titer, making this plant a model plant for phytoplasma studies (Ahrens and Seemüller 1992, Berges et al. 2000). The quantitative results are supported by the microscopic results. In the microscope, a large difference in SYTO 13 fluorescence is seen between $E$. pulcherrima and $C$. roseus, illustrating a large difference in infection levels similar to that found by Q-PCR quantification.

Table 2. Infection level in individual Euphorbia pulcherrima and Catharanthus roseus plants analysed with TaqMan assay

\begin{tabular}{|c|c|c|c|c|c|c|}
\hline Species, plant & Branching & Organ & $\begin{array}{c}\mathrm{C}_{\mathrm{T}}, 16 \mathrm{~S} \\
\text { (phytoplasma) }\end{array}$ & $\begin{array}{l}\mathrm{C}_{\mathrm{T}}, 18 \mathrm{~S} \\
\text { (plant) }\end{array}$ & $\begin{array}{l}\text { Normalized mean quantity } \\
\quad(\text { cells/ } \mu \text { g plant DNA })\end{array}$ & $\begin{array}{c}\text { Relative amount } \\
\text { compared with root in } \\
\text { plant } A \text { or } E\end{array}$ \\
\hline \multicolumn{7}{|l|}{ E. pulcherrima } \\
\hline \multirow[t]{3}{*}{ A (infected) } & + & Root & $31.68 \pm 0.37$ & $13.84 \pm 0.29$ & $2.2 \times 10^{3}$ & 1 \\
\hline & & Stem & $31.85 \pm 0.85$ & $17.26 \pm 0.17$ & $1.7 \times 10^{4}$ & 8 \\
\hline & & Source petiole & $30.43 \pm 0.49$ & $17.94 \pm 0.36$ & $6.3 \times 10^{4}$ & 29 \\
\hline \multirow[t]{3}{*}{ B (infected) } & +++ & Root & $28.49 \pm 0.89$ & $14.78 \pm 0.52$ & $3.6 \times 10^{4}$ & 17 \\
\hline & & Stem & $27.47 \pm 0.15$ & $16.18 \pm 0.14$ & $1.7 \times 10^{5}$ & 78 \\
\hline & & Source petiole & $25.37 \pm 0.18$ & $15.08 \pm 0.26$ & $3.7 \times 10^{5}$ & 172 \\
\hline \multirow[t]{3}{*}{$\mathrm{C}$ (infected) } & + & Root & $29.84 \pm 0.46$ & $14.01 \pm 0.11$ & $6.6 \times 10^{3}$ & 3 \\
\hline & & Stem & $29.94 \pm 0.14$ & $16.90 \pm 0.27$ & $4.6 \times 10^{4}$ & 21 \\
\hline & & Source petiole & $32.03 \pm 0.44$ & $19.93 \pm 0.34$ & $6.7 \times 10^{4}$ & 32 \\
\hline D (healthy) & - & Source leaf & $\ldots$ & $15.02 \pm 0.09$ & $\ldots$ & $\ldots$ \\
\hline Water & & $\ldots$ & $\ldots$ & $\ldots$ & $\ldots$ & $\ldots$ \\
\hline \multicolumn{7}{|l|}{ E. pulcherrima } \\
\hline \multirow[t]{4}{*}{ E (infected) } & + & Root & $31.04 \pm 0.48$ & $16.39 \pm 0.64$ & $5.3 \times 10^{2}$ & 1 \\
\hline & & Stem & $28.13 \pm 0.75$ & $15.89 \pm 0.55$ & $3.5 \times 10^{3}$ & 7 \\
\hline & & Source leaf & $24.91 \pm 0.31$ & $17.45 \pm 0.33$ & $2.2 \times 10^{4}$ & 41 \\
\hline & & Sink leaf & $\ldots$ & $18.39 \pm 0.31$ & $\ldots$ & $\ldots$ \\
\hline F (healthy) & - & Source leaf & $\ldots$ & $13.41 \pm 0.76$ & $\ldots$ & $\ldots$ \\
\hline \multicolumn{7}{|l|}{ C. roseus } \\
\hline G (infected) & & Shoot & $17.98 \pm 0.01$ & $15.79 \pm 0.14$ & $4.8 \times 10^{6}$ & 9,054 \\
\hline H (healthy) & & Shoot & $\ldots$ & $14.81 \pm 0.22$ & $\ldots$ & $\ldots$ \\
\hline Water & & $\ldots$ & $\ldots$ & $\ldots$ & $\ldots$ & $\ldots$ \\
\hline
\end{tabular}

${ }^{a}$ Data represents two TaqMan assays, the first including plants A to D and the second plants $\mathrm{E}$ to $\mathrm{H}$. 
The bioimaging method presented here allows the detection of phytoplasmas in living plant tissue and also can identify sieve elements, companion cells, sieve pores, and the symplasmic contacts linking them. The DNA-specific dye DAPI, which demands fixation for in-depth tissue penetration in plants (Schulz 1987) was replaced with the vital dye SYTO 13 (Hansen et al. 2000), and confocal laser and multiphoton scanning microscopy was used to achieve a high level of resolution in three dimensions and to avoid tissue damage. The presence of DNA in mature sieve elements is a sufficient marker for phytoplasmas because mature sieve elements are devoid of a nucleus. Neither sieve-element plastids nor mitochondria preserve a notable amount of DNA, as indicated by the lack of DNA fluorescence in uninfected sieve tubes of the controls.

In order to gain insights into the vitality of phytoplasmas, $\mathrm{DiOC}_{7}(3)$, a potentiometric dye visualizing only those organelles or bacteria that exhibit a membrane potential (Liu et al. 1987; Thrane et al. 1999), was used. Accordingly, phytoplasmas were stained with this dye only when they were living and active, whereas SYTO 13 was positive for both viable and
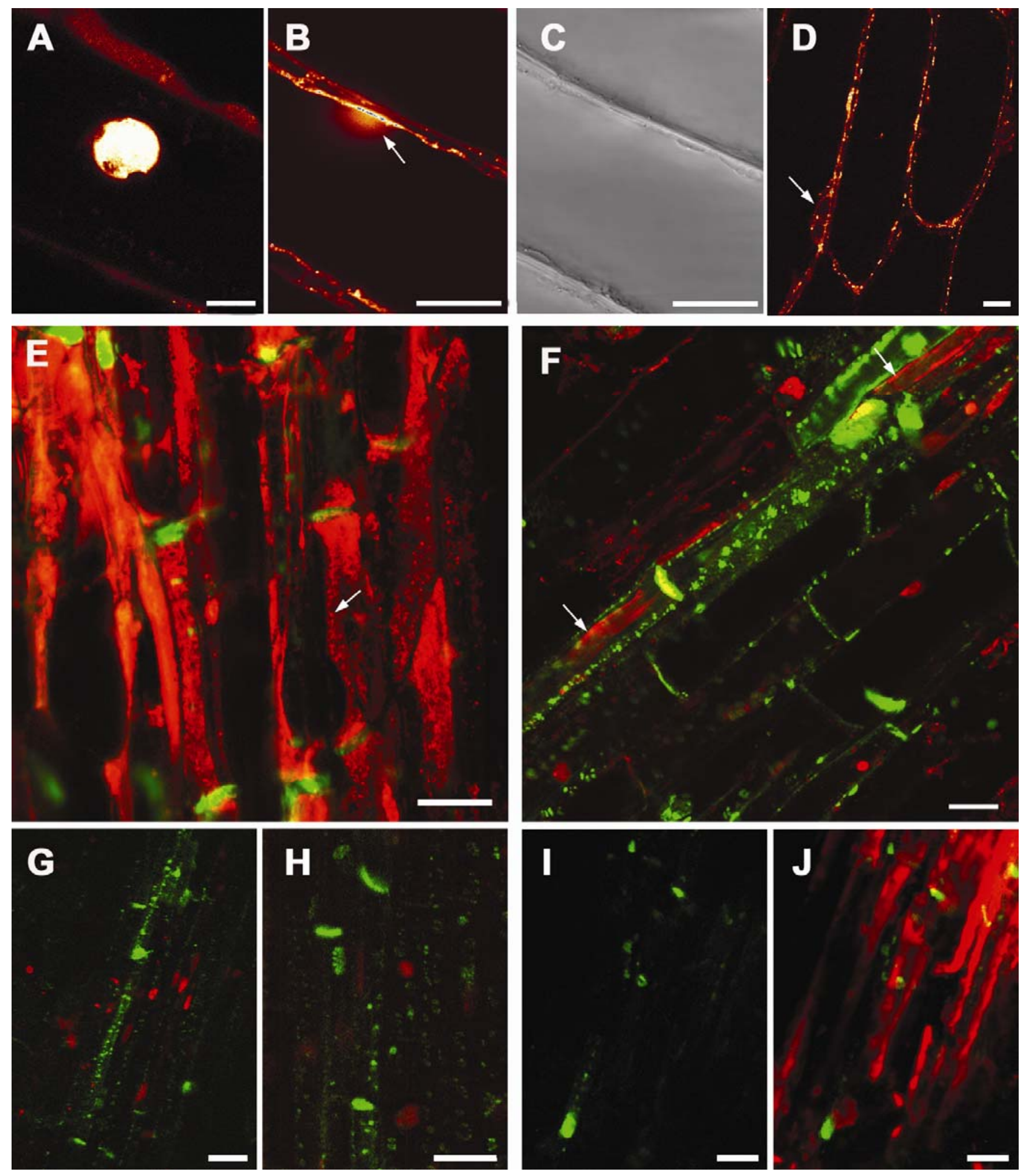
dead (or inactive) phytoplasmas. Subsequent application of the dyes showed a blending of viable and nonviable phytoplasmas in heavily infected sieve tubes. The loss of membrane potential of phytoplasmas might be due to their high density in the target tissue or to tissue preparation which, in sieve tubes, is accompanied by a sudden pressure release.

Data on the closely related mycoplasmas indicated that they have a membrane potential of $\approx-50$ to $-72 \mathrm{mV}$ which is generated by a membrane-bound electrogenic, proton-translocating adenosine triphosphatase (Schiefer and Schummer 1982). In contrast to mycoplasmas, phytoplasma does not appear to contain any genes coding for ATP-synthase subunits (Oshima et al. 2004). Visualization of viable phytoplasmas by a potentialsensitive dye opens the question of how the membrane potential is generated in an organism without an apparent ATP-synthase. The predicted incompleteness of sucrose phosphorylase in the genome (Oshima et al. 2004) is another example of highly specialized physiology of phytoplasmas, just in the light of the high sucrose concentration phytoplasmas experience in sieve tubes. Bioimaging indicators will help to elucidate the enigmatic physiology of phytoplasmas.

Q-PCR assays have been used to detect or quantify other microorganisms in a range of different environments and have the potential to dramatically improve knowledge of the ecology of microorganisms. The combination of methods reported here, Q-PCR assays and bioimaging, offers a breakthrough for studying the interaction of phytoplasmas with their host plants, including the effects of the endoparasite on assimilate transport and the mechanism of its systemic movement in the host.

\section{MATERIALS AND METHODS}

\section{Plant material.}

E. pulcherrima (Willd. ex. Klotzsch) cv. Angelika, healthy and infected plants with branch-inducing phytoplasmas (PoiBI; strain 16SrIII subgroup H) (Bradel et al. 2000; Lee et al. 1998b) (supplied by W. Preil, Bundesanstalt für Züchtungsforschung an Kulturpflanzen, Institut für Zierpflanzenzüchtung, Ahrensburg, Germany) and $C$. roseus healthy and infected plants with the phytoplasma strains PYLR (peach yellow leaf roll) or GVX (green valley X) (supplied by E. Seemüller, Institut für Pflanzenschutz im Obstbau, Dossenheim, Germany) were grown in a greenhouse with a daily cycle of $16 \mathrm{~h}$ of day and 8 $\mathrm{h}$ of night under artificial daylight (Osram Vialox Planta-Ts, Munich, Germany; lamp) in addition to natural daylight, giving a minimum photon flux of $135 \mu \mathrm{mol} \mathrm{m} \mathrm{m}^{-2} \mathrm{~s}^{-1}$ PAR. The temperature range was between 18 and $30^{\circ} \mathrm{C}$ during the period of sample collection (June). Infected and healthy E. pulcher- rima plants were propagated vegetatively. For propagation of infected $C$. roseus, healthy plants were inoculated periodically by grafting. Control and infected plant material was always of the same age: 3 to 6 months for E. pulcherrima and 1 to 3 months for $C$. roseus. Samples for DNA-extraction and microscopic examinations were taken from the same plants. There were no phytoplasma vectors present in the greenhouse.

\section{DNA extraction.}

DNA from E. pulcherrima and C. roseus was extracted from $100 \mathrm{mg}$ of ground (wet weight) plant tissue according to the DNeasy Plant Mini Kit protocol (Qiagen, Hilden, Germany). DNA was eluted in $100 \mu$ l of elution buffer. For root samples, root tips within plants (the apical $3 \mathrm{~cm}$ of lateral roots) were pooled. For stem samples, one internode per plant was collected. For petioles, four petioles from source leaves per plant were pooled. Mature sources of E. pulcherrima were defined as approximately $15 \mathrm{~cm}$ in length and unfolding sink leaves as pale green and shorter than $3 \mathrm{~cm}$. Shoot samples from $C$. roseus were young side branches of 4 to $5 \mathrm{~cm}$ in length.

Samples of DNA from a variety of phytoplasma strains (Table 1) grown in C. roseus and grapevine were supplied by A. Bertaccini (Dipartimento di Scienze e Tecnologie Agroambientali, Bologna, Italy). This DNA had been extracted following the method of Prince and associates (1993).

\section{Oligonucleotide primers and probes.}

Primers and probes used for the Q-PCR assay in this study were designed using Primer Express software (version 2.0; Applied Biosystems, Foster City, CA, U.S.A.) (Table 3). Probes and primers for phytoplasma detection were based on alignments of $16 \mathrm{~S}$ rDNA obtained from GenBank from a range of phytoplasma strains (one of each phytoplasma $16 \mathrm{Sr}$ group) (Lee et al. 1998b), bacteria, and mycoplasmas. Primers were designed to amplify DNA from a broad range of phytoplasma strains, excluding amplification of bacterial DNA. The fluorogenic probe was synthesized by Applied Biosystems and was 5 ' labeled with the reporter dye FAM (6-carboxyfluorescein) and $3^{\prime}$ labeled with the quenching dye TAMRA (6-carboxytetramethylrhodamine).

Probe and primers to amplify plant DNA for a normalization of PCR results were based on alignments of $18 \mathrm{~S}$ rDNA sequences obtained from GenBank from a broad variety of plants representing families in the gymnosperms (Selaginella, Gingko, and Pinus), dicots (Lycopersicon, Glycine, Buxus, Gossypium, and E. pulcherrima), and monocots (Zea and Oryza). The probes and primers were designed to amplify DNA from as many different plant species as possible. The fluorogenic probe was labeled with VIC and TAMRA at the 5' and 3 ' ends, respectively.

Fig. 3. A through D, Confocal laser scanning micrographs of Allium cepa bulb scale epidermis to confirm $\mathrm{SYTO}_{13}$ and DiOC 7 (3) as vital dyes. A, Epidermis stained with SYTO 13. The nucleus and small organelles, most likely mitochondria, in the cytoplasm are fluorescent. B, Epidermis stained with SYTO 13. The fluorescent dots correspond in size with mitochondria (see C) and were moving along with cytoplasmic streaming. The nucleus is located just below the focal plane (arrow). C, Transmission differential interference contrast micrograph of the same area as B. D, A. cepa epidermis peel stained with $\operatorname{DiOC}_{7}(3)$. Organelles in the cytoplasm are stained, but not the nucleus (arrow). E through $\mathbf{J}$, Localization of phytoplasmas in the phloem with the DNAspecific SYTO 13 using two-channel multiphoton/confocal laser scanning microscopy. E, Longitudinal section of phytoplasma-infected C. roseus stem stained with SYTO 13 (red channel) and aniline blue identifying callose (green channel). SYTO 13 fluorescence (red) is massive between sieve plates (green fluorescence). In less densely stained sieve elements, SYTO 13-positive particulate structures can be distinguished (arrow), the small size of which corresponds to phytoplasma. F, Longitudinal sections of phytoplasma-infected Euphorbia pulcherrima petiole stained with SYTO 13 (red) and aniline blue (green). SYTO 13 fluorescence appears only in some of the sieve elements (arrows). G, Longitudinal sections of phytoplasma-infected E. pulcherrima petiole stained with SYTO 13 (red) and aniline blue (green). Red fluorescence identifies nuclei and mitochondria in parenchyma cells, but does not show up in the sieve tubes identified by sieve-pore callose. H, Longitudinal section of healthy C. roseus stem (control) stained with SYTO 13 (red) and aniline blue (green). The callose of the sieve plate clearly stained with aniline blue. Some of the phloem parenchyma cells show a nucleus (red), but there is no red signal in the sieve tubes. I, Longitudinal section of phytoplasma-infected $C$. roseus stem stained with aniline blue (green channel) alone. The callose of the sieve plates is seen. The SYTO 13 channel is open and set to high sensitivity, but there is no autofluorescence in the phloem. J, The same section as I, SYTO 13 is added (red). The fluorescence of aniline blue (green) is still present; the SYTO 13 fluorescence (red) marks a heavy accumulation of phytoplasmas between sieve plates. A through J, Bars: $20 \mu \mathrm{m}$. 


\section{Standard curves and normalization.}

Two standard curves were made, one for phytoplasma quantification and one for plant DNA quantification. To obtain DNA to use for the phytoplasma standard curve, DNA from infected $E$. pulcherrima was amplified with the universal primer pair R16F0/R16R0 (Davis and Lee 1993), followed by nested PCR
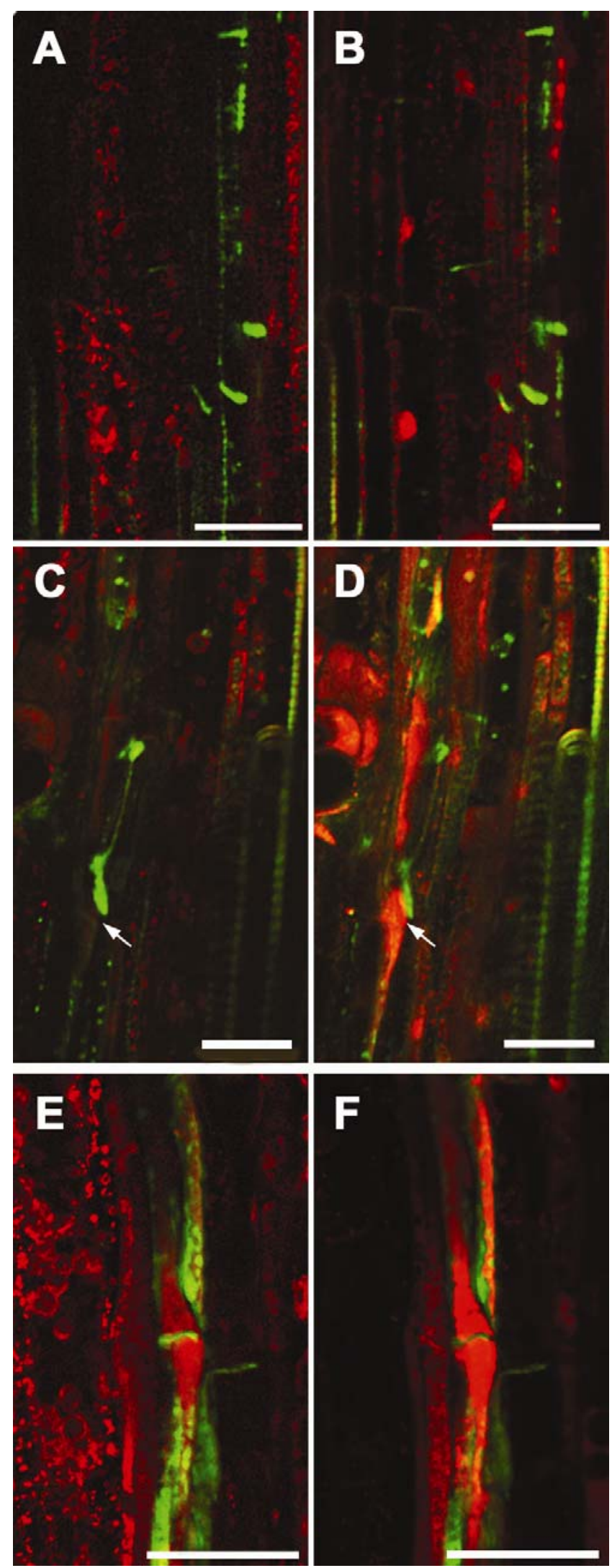

with X-disease-specific primer pairs F45/R45 (Abad et al. 1997). Products of the first PCR were diluted 100-fold before nested PCR. PCR cycling parameters for both primary and nested PCR were $94^{\circ} \mathrm{C}$ for 3 min followed by 35 cycles at $94^{\circ} \mathrm{C}$ for $30 \mathrm{~s}, 55^{\circ} \mathrm{C}$ for $30 \mathrm{~s}$, and $72^{\circ} \mathrm{C}$ for $90 \mathrm{~s}$, and finally $72^{\circ} \mathrm{C}$ for $10 \mathrm{~min}$. The amount of input DNA in both standard curves was estimated using gel electrophoresis with standards of known concentration. For the standard curve, the obtained amplicon was diluted 10-fold in a series $\left(10^{-5}, 10^{-7}, 10^{-8}, 10^{-9}, 10^{-10}, 10^{-11}\right)$ and a Q-PCR assay was run as stated below. For the plant DNA standard curve, one of the extracted healthy samples was diluted 10 -fold in a series of six dilutions.

The amount of input DNA and the size of the PCR product was known for the phytoplasma standard curve; therefore, the number of DNA copies could be calculated for each sample. Hence, the number of phytoplasma cells would be half of this because two copies of the gene exist in phytoplasmas (Oshima et al. 2004; Schneider and Seemüller 1994). Normalization of phytoplasma quantities was performed by running Q-PCR assays for plant rDNA from each sample. The phytoplasma amount was divided with the amount of plant DNA in each sample to obtain number of phytoplasma cells per microgram of plant DNA. The $18 \mathrm{~S}$ plant standard curve used in Table 2 has been produced using an E. pulcherrima DNA dilution series. The result was confirmed later with a $C$. roseus DNA dilution series.

\section{Q-PCR assay and quantification.}

Primer and probe concentrations were optimized for each assay according to the manufacturer's instructions (Applied Biosystems). The optimized Q-PCR assay for phytoplasma was $300 \mu \mathrm{M}$ forward primer, $900 \mu \mathrm{M}$ reverse primer, $200 \mu \mathrm{M}$ probe, 1× TaqMan universal PCR Master Mix (Applied Biosystems), $1 \mu$ l of template, and Milli $Q$ water to a final volume of $25 \mu \mathrm{l}$. For plant $18 \mathrm{~S}$ rDNA, conditions were the same except that $900 \mu \mathrm{M}$ forward primer and $300 \mu \mathrm{M}$ reverse primer were used. Samples were tested in triplicate. The Q-PCR assay started with $2 \mathrm{~min}$ at $50^{\circ} \mathrm{C}$ and $10 \mathrm{~min}$ at $95^{\circ} \mathrm{C}$ followed by 40 cycles of amplification, $15 \mathrm{~s}$ at $95^{\circ} \mathrm{C}$ and $1 \mathrm{~min}$ at $60^{\circ} \mathrm{C}$. The amplification, data acquisition, and data analysis were performed in an ABI PRISM 7000 Sequence Detection System (Applied Biosystems) installed with accompanying software

Fig. 4. Localization of phytoplasmas in the phloem with the membranepotential-sensitive dye $\operatorname{DiOC}_{7}(3)$ and SYTO 13 (image pairs) using twochannel multiphoton/confocal laser scanning microscopy. A, Longitudinal section of healthy Catharanthus roseus (control) stained with $\mathrm{DiOC}_{7}(3)$ (red) and aniline blue (green). The sieve plates fluoresce green. Red fluorescence is restricted to organelles (chloroplasts and mitochondria) of parenchyma cells. No $\mathrm{DiOC}_{7}(3)$ fluorescence is detectable in the sieve tubes. B, Same section as A, $\operatorname{DiOC}_{7}(3)$ is replaced with SYTO 13 (red). The fluorescence of aniline blue (green), marking the sieve tubes, is still present; nuclei in parenchyma cells fluoresce red. SYTO 13 fluorescence is not detectable in the sieve tubes. $\mathbf{C}$, Longitudinal section of infected $C$. roseus stained with $\mathrm{DiOC}_{7}(3)$ (red) and aniline blue (green). Sieve plates (green) and organelles in parenchyma cells (red) are positive. $\mathrm{DiOC}_{7}(3)$ fluorescence is not detectable in a heavily infected sieve element (arrow), even though infection is present (see D). D, Same section as seen in C, $\mathrm{DiOC}_{7}(3)$ is replaced with SYTO 13 (red). The fluorescence of aniline blue (green) is still present. Sieve elements without fluorescence after $\mathrm{DiOC}_{7}(3)$ staining now do show SYTO 13 fluorescence (arrow). E, Longitudinal section of infected $C$. roseus stained with $\operatorname{DiOC}_{7}(3)$ (red) and aniline blue (green). Organelles in the parenchyma cells appear red. In addition, there is strong $\operatorname{DiOC}_{7}(3)$ fluorescence in the sieve tubes, which also show pronounced aniline blue fluorescence. F, The same section as seen in $\mathrm{D}, \mathrm{DiOC}_{7}(3)$ is replaced with SYTO 13 (red). The fluorescence of aniline blue (green) is still present. The same sieve tubes that showed fluorescence with $\operatorname{DiOC}_{7}(3)$ now have SYTO 13 fluorescence. A through F, Bars: $40 \mu \mathrm{m}$. 
Table 3. Sequence of primers and probes designed for detection of phytoplasma and plant DNA

\begin{tabular}{lll}
\hline Primer or probe & \multicolumn{1}{c}{ Phytoplasma 16S rDNA } & \multicolumn{1}{c}{ Plant 18S rDNA } \\
\hline Forward primer & 5' CGTACGCAAGTATGAAACTTAAAGGA & 5' GACTACGTCCCTGCCCTTTG \\
Probe & 5' TGACGGGACTCCGCACAAGCG & 5' ACACACCGCCCGTCGCTCC \\
Reverse primer & 5' TCTTCGAATTAAACAACATGATCCA & 5' AACACTTCACCGGACCATTCA \\
\hline
\end{tabular}

version 1.0. The PCR cycle in which fluorescence exceeds baseline fluorescence is the threshold cycle $\left(\mathrm{C}_{\mathrm{T}}\right)$. For the graphic presentations, the $\mathrm{C}_{\mathrm{T}}$ values were exported to Sigma Plot for further analysis. For linear regression, least squares are used to fit a set of data points $(x i, y i) i=1, \ldots, n$ to a polynomial of order $p$ where: $y=\beta_{0}+\beta_{1} X+\beta_{2} X^{2}+\ldots+\beta_{\mathrm{p}} \mathrm{X}^{\mathrm{p}}$

In order to test sensitivity, dilution series were made from a DNA sample of an infected $C$. roseus shoot and an infected $E$. pulcherrima leaf. The dilution series were analyzed with QPCR assays and, for comparison, nested PCR as described above with R16F0/R16R0 (Davis and Lee 1993) and then with F45/R45 (Abad et al. 1997) as primer pairs.

To evaluate the reliability of quantification by the Q-PCR assay, crude homogenates of plant material from infected and healthy shoot tissue of $C$. roseus were mixed in known proportions $(100,75,50,33,11,6,1$, and $0 \%$ infected material). The samples were analyzed with Q-PCR assays.

Any false-positive contribution of bacterial DNA to the assay was checked by performing the Q-PCR assay on pure DNA from the following bacterial species: Agrobacterium radiobacter, Arthrobacter globiformis, A. oxydans, Bacillus gibsonii, B. megaterium, Clavibacter michiganense, Paenibacillus macerans, Pseudomonas putida, Ralstonia pickettii, and Rhodococcus equi (Table 1).

\section{Bioimaging of phytoplasma infection.}

In order to visualize phytoplasmas and identify sieve tubes, three dyes were tested. These stained DNA, membranes with a high membrane potential, and callose, respectively. SYTO 13 (green fluorescent nucleic acid stain) and $\mathrm{DiOC}_{7}(3)$ (3,3'-diheptyloxacarbocyanine iodide) were purchased from Molecular Probes (Leiden, The Netherlands) and aniline blue from Merck (Darmstadt, Germany). Stock solutions of SYTO 13 and $\mathrm{DiOC}_{7}(3)$ were prepared in dimethyl sulfoxide (DMSO; 1 $\mathrm{mg} / \mathrm{ml}$ ), and of aniline blue in $0.1 \mathrm{M}$ phosphate buffer, $\mathrm{pH} 7.4$ $(0.05 \mathrm{mg} / \mathrm{ml})$.

A. cepa epidermis peels were used as a model system to test for dyes able to stain fresh plant material and the approximate concentration needed, and to obtain emission spectra of the dye in question. A. cepa peels were stained for $15 \mathrm{~min}$ with SYTO $13(0.5 \mu \mathrm{l} / \mathrm{ml})$ or $\mathrm{DiOC}_{7}(3)(0.2 \mu \mathrm{l} / \mathrm{ml})$. Fresh hand sections of the $E$. pulcherrima and $C$. roseus petioles and stems, respectively, were placed into SYTO $13(0.5 \mu \mathrm{l} / \mathrm{ml})$ or $\operatorname{DiOC}_{7}(3)(0.02 \mu \mathrm{l} / \mathrm{ml})$ for 15 minutes. SYTO 13 -stained sections were counterstained for 2 to $5 \mathrm{~min}$ by adding to the staining solution approximately $50 \mu \mathrm{l}$ of aniline blue $(5 \mu \mathrm{l} / \mathrm{ml})$ at the end of incubation. Double staining of aniline blue and $\mathrm{DiOC}_{7}(3)$ was done by adding them consecutively with a washing step in between.

A multiphoton confocal laser scanning microscope (Leica TCS SP2/MP; Leica Microsystems, Bensheim, Germany) equipped with an argon ion and a multiphoton laser was used to detect the fluorescence signal of SYTO 13, $\operatorname{DiOC}_{7}(3)$, and aniline blue from the stained plant tissue. The following objectives were used: HC PL APO $\times 10 / 0.40$, HC PL APO $\times 20 / 0.70$ W, HCX PL APO $\times 63 / 1.20 \mathrm{~W}, \mathrm{HCX}$ APO L $\times 40 / 0.80 \mathrm{~W}$, and HCX APO L $\times 63 / 0.90 \mathrm{~W}$. SYTO 13 and $\mathrm{DiOC}_{7}(3)$ both were excited with $488 \mathrm{~nm}$ and emission was recorded at 510 to 560 $\mathrm{nm}$ and 500 to $540 \mathrm{~nm}$, respectively. Aniline blue was excited at $800 \mathrm{~nm}$ and emission was recorded at 450 to $510 \mathrm{~nm}$. When aniline blue was viewed together with one of the other dyes, the images were recorded by sequential frame scanning. To confirm specificity of SYTO 13 or $\operatorname{DiOC}_{7}(3)$ fluorescence, a lambda scan was performed from 495 to $595 \mathrm{~nm}$ (10 steps of $10 \mathrm{~nm}$ or 20 steps of $5 \mathrm{~nm}$, respectively). The signal of SYTO 13 also was detected with a conventional fluorescence microscope (Zeiss Photomikroskop II).

In order to compare staining with $\operatorname{DiOC}_{7}(3)$ or SYTO 13, a system was developed where is was possible to change the dye while viewing. The specimen was glued to the object glass with medical adhesive (Holliser Inc. Libertyville, IL), which is nontoxic (cytoplasmic streaming continues in A. cepa). The dye in question was added and the specimen was viewed with objectives that dip directly into the medium ("dipping lenses"; Leica Microsystems HCX APO L ×40/0.80 W and HCX APO $\mathrm{L} \times 63 / 0.90 \mathrm{~W})$. A glass tube connected to a suction device was positioned close to the surface of the medium. When new dyesolution was added by pipette, the surface raised and excess liquid was removed automatically by suction. Interference between $\mathrm{DiOC}_{7}(3)$ or SYTO 13 was avoided by a washing step.

\section{ACKNOWLEDGMENTS}

This work was supported by the Danish Biotechnological Instrument Center. The authors would like to thank A. Bertaccini, (Dip. di Scienze e Tecnologie Agroambientali, University of Bologna, Italy) for provision of DNA samples from a variety of phytoplasma strains, E. Seemüller (Institut für Pflanzenschutz im Obstbau, Dossenheim, Germany) for provision of C. roseus infected with the strains PYLR and GVX, and W. Preil (Bundesanstalt für Züchtungsforschung an Kulturpflanzen, Ahrensburg) for provision of E. pulcherrima infected with an X-disease phytoplasma.

\section{LITERATURE CITED}

Abad, J. A., Randall, C., and Moyer, J. W. 1997. Factors influencing detection of phytoplasmas associated with Poinsettia. (Abstr.) Phytopathology 87:S1.

Ahrens, U., and Seemüller, E. 1992. Detection of DNA of plant pathogenic mycoplasmalike organisms by a polymerase chain reaction that amplifies a sequence of the $16 \mathrm{~S}$ rRNA gene. Phytopathology 82:828-832.

Bates, J. A., Taylor, E. J. A., Kenyon, D. M., and Thomas, J. E. 2001. The application of real-time PCR to the identification, detection and quantification of Pyrenophora species in barley seed. Mol. Plant Pathol. 2:49-57.

Berges, R., Rott, M., and Seemüller, E. 2000. Range of phytoplasma concentrations in various plant hosts as determined by competitive polymerase chain reaction. Phytopathology 90:1145-1152.

Blomquist, C. L., and Kirkpatrick, B. C. 2002. Frequency and seasonal distribution of pear psylla infected with the pear decline phytoplasma in California pear orchards. Phytopathology 92:1218-1226.

Bradel, B. G., Preil, W., and Jeske, H. 2000. Remission of the free-branching pattern of Euphorbia pulcherrima by tetracycline treatment. J. Phytopathol. 148:587-590.

Constable, F. E., Gibb, K. S., and Symons, R. H. 2003. Seasonal distribution of phytoplasmas in Australian grapevines. Plant Pathol. 52:267-276.

Davis, R. E., and Lee, I.-M. 1993. Cluster-specific polymerase chain reaction amplification of $16 \mathrm{~S}$ rDNA sequences for detection and identification of mycoplasmalike organisms. Phytopathology 83:1008-1011.

Deeley, J., Stevens, W. A., and Fox, R. T. V. 1979. Use of Dienes' stain to detect plant diseases induced by mycoplasma-like organisms. Phytopathology 69:1169-1171.

Garcia-Chapa, M., Medina, V., Viruel, M. A., Laviña, A., and Batlle, A. 2003. Seasonal detection of pear decline phytoplasma by nested PCR in different pear cultivars. Plant Pathol. 52:513-520.

Giulietti, A., Overbergh, L., Valckx, D., Decallonne, B., Bouillon, R., and Mathieu, C. 2001. An overview of real-time quantitative PCR: applications to quantify cytokine gene expression. Methods 25:386-401. 
Hansen, M., Thrane, C., Olsson, S., and Sørensen, J. 2000. Confocal imaging of living fungal hyphae challenged with the fungal antagonist viscosinamide. Mycologia 92:216-221.

Hristova, K. R., Lutenegger, C. M., and Scow, K. M. 2001. Detection and quantification of methyl tert-butyl ether- degrading strain PM1 by realtime TaqMan PCR. Appl. Environ. Microbiol. 67:5154-5160.

Jarausch, W., Lansac, M., Saillard, C., Broquaire, J. M., and Dosba, F. 1998. PCR assay for specific detection of European stone fruit yellows phytoplasmas and its use for epidemiological studies in France. Eur. J. Plant. Pathol. 104:17-27.

Kuske, C. R., and Kirkpatrick B. C. 1992. Distribution and multiplication of western aster yellows mycoplasmalike organisms in Catharanthus roseus as determined by DNA hybridization analysis. Phytopathology 82:457-462.

Laimer da Câmara Machado, M., Paltrinieri, S., Hanzer, V., Arthofer, W., Strommer, S., Martini, M., Pondrelli, M., and Bertaccini, A. 2001. Presence of European stone fruit yellows (ESFY or $16 \mathrm{SrX}-\mathrm{B})$ phytoplasmas in apricots in Austria. Plant Pathol. 50:130-135.

Lederer, W., and Seemüller, E. 1992. Demonstration of mycoplasmas in Prunus species in Germany. J. Phytopathol. 134:89-96.

Lee, I.-M., Davis, R. E., and Gundersen-Rindal, D. E. 2000. Phytoplasma: phytopathogenic mollicutes. Annu. Rev. Microbiol. 54:221-255.

Lee, I.-M., Gundersen-Rindal, D. E., and Bertaccini, A. 1998a. Phytoplasma: Ecology and genomic diversity. Phytopathology 88:13591366.

Lee, I.-M., Gunderson-Rindal, D. E., Davis, R. E., and Bartosyzk, I. M. 1998b. Revised classification scheme of phytoplasmas based on RFLP analyses of $16 \mathrm{~S}$ rRNA and ribosomal protein gene sequences. Int. J. Syst. Bacteriol. 48:1153-1169

Lee, I.-M., Klopmeyer, M., Bartoszyk, I. M., Gundersen-Rindal, D. E., Chou, T.-S., Thomsen, K. L., and Eisenreich, R. 1997a. Phytoplasma induced free-branching in commercial poinsettia cultivars. Nat. Biotechnol. 15:178-182.

Lee, I.-M., Pastore, M., Vibio, M., Danielli, A., Attathom, S., Davis R. E., and Bertaccini, A. 1997b. Detection and characterization of a phytoplasma associated with annual blue grass (Pоа апnиа) white leaf disease in southern Italy. Eur. J. Plant. Pathol. 103:251-254.

Lepka, P., Stitt, M., Moll, E., and Seemüller, E. 1999. Effect of phytoplasmal infection on concentration and translocation of carbohydrates and amino acids in periwinkle and tobacco. Physiol. Mol. Plant Physiol. 55:59-68.

Lim, P.-O., and Sears, B. B. 1989. 16S rRNA sequence indicates that plant-pathogenic mycoplasmalike organisms are evolutionarily distinct from animal mycoplasmas. J. Bacteriol. 171:5901-5906.

Liu, Z., Bushnell, W. R., and Brambl, R. 1987. Potentiometric cyanine dyes are sensitive probes for mitochondria in intact plant cells. Kinetin enhances mitochondrial fluorescences. Plant Physiol. 84:13851390.

McCoy, R. E., Caldwell, A., Chang, C. J., Chen, T. A., Chiykowski, L. N., Cousin, M. T., Dale, J. L., Leeuw, G. T. N., Golino, D. A., Hackett, K. J., Kirkpatrick, B. C., Marwitz, R., Petzold, H., Sinha, R. C., Whitcomb, R. F., Yang, I. L., Zhu, B. M., and Seemüller, E. 1989. Spiroplasmas, Acholeplasmas, and Mycoplasmas of plants and Arthropods. Pages 545-640 in: The Mycoplasma, Vol V. R. F. Whitcomb and G. Tully, eds. Academic Press, New York.

Oshima K., Kakizawa S., Nishigawa H., Jung H.-Y., Wei W., Suzuki S., Arashida R., Nakata D., Miyata S., Ugaki M., and Namba S. 2004. Reductive evolution suggested from the complete genome sequence of a plant-pathogenic phytoplasma. Nat. Genet. 36:27-29.

Prince, J. P., Davis, R. E., Wolf, T. K., Lee, I.-M., Mogen, B. D., Dally, E. L., Bertaccini, A., Credi, R., and Barda, M. 1993. Molecular detection of diverse mycoplasmalike organisms (MLOs) associated with grape- vine yellows and their classification with aster yellows, $\mathrm{X}$-disease and elm yellows MLOs. Phytopathology 83:1130-1137.

Roberts, C. A., Dietzgen, R. G., Heelan, L. A., and Maclean, D. J. 2000. Real-time RT-PCR fluorescent detection of tomato spotted wilt virus. J. Virol. Methods 88:1-8.

Rudzinska-Langwald, A., and Kaminska, M. 1999. Cytopathological evidence for transport of phytoplasma in infected plants. Acta Soc. Bot. Pol. 68:261-266.

Schaper U., and Seemüller E. 1984. Recolonization of the stem of apple proliferation and pear decline-diseased trees by the causal organisms in spring. Z. Pflanzenkrankh. Pflanzenschutz 91:608-613.

Schiefer H. G., and Schummer U. 1982. The electrochemical potential across mycoplasmal membranes. Rev. Infect. Dis. 4(Suppl):S65-70.

Schneider, B., and Seemüller, E. 1994. Presence of two sets of ribosomal genes in phytopathogenic mollicutes. Appl. Environ. Microbiol. 60:3409-3412.

Schulz, A. 1987. Sieve-element differentiation and fluoresceine translocation in wound-phloem of pea roots after complete severance of the stele. Planta 170:289-299.

Schulz, A., Kühn, C., Riesmeier, J. W., and Frommer, W. B. 1998. Ultrastructural effect in potato leaves due to antisense-inhibition of the sucrose transporter indicate an apoplasmic mode of phloem loading. Planta 206:533-543.

Seemüller, E., Schaper, U., and Zimbelmann, F. 1984. Seasonal variation in the colonization patterns of mycoplasmalike organisms associated with apple proliferation and pear decline. Z. Pflanzenkrankh. Pflzenschutz 91:525-532.

Seemüller, E., Schneider, B., Mäurer, R., Ahrens, U., Daire, X., Kison, H., Lorenz, K.-H., Firrao, G., Avinent, L., Sears B. B., and Stackebrandt, E. 1998. Phylogenetic classification of phytopathogenic mollicutes by sequence analysis of 16 S ribosomal DNA. Int. J. Syst. Bacteriol. 44:440446.

Siddique, A. B. M, Guthrie, J. N., Walsh, K. B., White, D. T., and Scott, P. T. 1998. Histopathology and within-plant distribution of the phytoplasma associated with Australian papaya dieback. Plant Dis. 82:1112-1120

Siller, W., Kuhbandner, B., Marwitz, R., Petzold, H., and Seemüller, E. 1987. Occurrence of mycoplasma-like organisms in parenchyma cells of Cuscuta odorata (Ruiz et Pav.). J. Phytopathol. 119:147-159.

Sinclair, W. A., Townsend, A. M., Griffiths H. M., and Whitlow, T. H. 2000. Response of six Eurasian Ulmus cultivars to a North American elm yellows phytoplasma. Plant Dis. 84:1266-1270.

Shi, L., Ho, J., Norling, L. A., Roy, M., and Xu, Y. 1999. A real-time quantitative PCR-based method for the detection and quantification of simian virus 40. Biologicals 27:241-252.

Suzuki, M. T., Taylor, L. T., and DeLong, E. 2000. Quantitative analysis of small-subunit rRNA genes in mixed microbial populations via $5^{\prime}$-nuclease assays. Appl. Environ. Microbiol. 66:4605-4614.

Thrane, C., Olsson, S., Nielsen T. H., and Sørensen, J. 1999. Vital fluorescent stains for detection of stress in Pythium ultimum and Rhizoctonia solani challenged with viscosinamide from Pseudomonas fluorescens DR54. FEMS (Fed. Eur. Microbiol. Soc.) Microbiol. Ecol. 30:11-23

Tully, J. G., Whitcomb, R. F., and Rose, D. L. 1994. Acholeplasma brassicae sp. NOV and Acholeplasma palmae sp. NOV2, Non-sterol-requiring mollicutes from plant surfaces. Int. J. Syst. Bacteriol. 44:680-684

Wei, W. Kakizawa, S., Suzuki, S., Jung, H.-Y. Nishigawa, H., Miyata, S., Oshima, K., Ugaki, M., Hibi, T., and Namba, S. 2004. In planta dynamic analysis of onion yellows phytoplasma using localized inoculation by insect transmission. Phytopathology 94:244-250.

Weller, S. A., Elphinstone, J. G., Smith, N. C., Boonham, N., and Stead, D. E. 2000. Detection of Ralstonia solanacearum strains with a quantitative, multiplex, real-time, fluorogenic PCR (TaqMan assay). Appl. Environ. Microbiol. 66:2853-2858. 